\title{
Extent of Implementation of Social Studies Curriculum in Secondary Schools in Enugu State
}

\author{
Dorothy Uchenna Akubuilo1, Anthonia Chinwe Ugo ${ }^{2 *}$, Donald Chukwuma Ugo ${ }^{3}$, \\ Jane Ijeoma Ugochukwu' ${ }^{4}$, Michael Ejime Ikehi ${ }^{5}$ \\ ${ }^{1}$ Department of Educational Foundations, Enugu State University of Science and Technology, Enugu, Nigeria \\ ${ }^{2}$ Department of Educational Foundations, Godfrey Okoye University, Enugu, Nigeria \\ ${ }^{3}$ Department of Industrial Mathematics and Statistics, Enugu State University of Science and Technology, Enugu, Nigeria \\ ${ }^{4}$ Department of Pharmaceutical Microbiology and Biotechnology, Enugu State University of Science and Technology, Enugu, Nigeria \\ ${ }^{5}$ Department of Agricultural Education, University of Nigeria, Nsukka, Nigeria \\ Email: dorokuent2003@yahoo.com, *sisterchinweugo@gmail.com, \\ donald.ugo@esut.edu.ng, ugoij@yahoo.com,michael.ikehi@unn.edu.ng
}

How to cite this paper: Akubuilo, D. U., Ugo, A. C., Ugo, D. C., Ugochukwu, J. I., \& Ikehi, M. E. (2019). Extent of Implementation of Social Studies Curriculum in Secondary Schools in Enugu State. Creative Education, 10, 2386-2399.

https://doi.org/10.4236/ce.2019.1011170

Received: September 26, 2019

Accepted: November 5, 2019

Published: November 8, 2019

Copyright $\odot 2019$ by author(s) and Scientific Research Publishing Inc. This work is licensed under the Creative Commons Attribution International License (CC BY 4.0).

http://creativecommons.org/licenses/by/4.0/

(c) (i) Open Access

\begin{abstract}
The study explored the extent of implementation of social studies curriculum in secondary schools in Enugu State. The study adopted descriptive survey research design and was guided by two research questions and two hypotheses. The population consisted of 339 social studies teachers. A structured questionnaire was used for data collection. Data collected were analyzed using mean and standard deviation. Findings of the study revealed that academic qualifications of teachers and location of the school influenced teacher's ability to implement social studies to a great extent. Teachers in urban secondary schools achieved higher content coverage than those in rural areas. The study thus, recommended the encouragement of secondary school teachers to pursue academic development to improve their performance. Regular workshops, seminars or on-the-job trainings should be organized by the ministry of education to update and upskill social studies teachers' knowledge and skills in content delivery.
\end{abstract}

\section{Keywords}

Social Studies, Academic-Qualifications, Knowledge, Curriculum, Implementation

\section{Introduction}

Education has been recognized as the root for all developments as it serves as a 
means to open door for national development and environmental sustainability. The national policy on education (Federal Republic of Nigeria, FRN, 2013) accepts education as an instrument for effective national development. According to Odey (2014), education was linked to a prototype or the laying of foundation of a building on a solid rock; meaning that education is the foundation on which our future is laid. Aja-Okorie (2013), for instance saw education as a powerful instrument in the making of a man or a woman in life, enabling the actualization of self-purpose and that of the society. Also, O' Conor as cited in Obasi, Kanno and Obih (2017) looked at education as a process by which society deliberately transmits cultural heritage to generations through schools, colleges and other tertiary institutions. At any point in time, education is necessary for societal and country's cultural, political and socioeconomic development (Ofojebe, 2014). Ikegbusi (2012) maintained that education has remained a systematic process through which every individual person acquires knowledge, skills, experience, and sound attitude. It makes an individual become civilized, refined and cultured. For Ikegbusi, education is the only means to make a society socialized; and the end purpose is to make the individual a holistic person. In the same light, Adesina (2011) asserted that education is a necessary force in the economic, intellectual, social and cultural empowerment. Adesina continued that education has the capacity to bring about behavioural and character changes, as well as restructure capabilities for desired development especially through social studies.

Social studies subject is one of the subjects in junior secondary curriculum that could enable persons to achieve moral, societal and educational goals. Social studies serve as an avenue to incorporate students into citizenship education, providing them with the knowledge, skills and attitudes that would make them competent and responsible citizens who are knowledgeable to contribute to the community, and display moral and civic excellence (National Council of the Social Studies, 2004). A great number of countries in the world introduced social studies in order to address certain goals, needs and ardent desires of their country. For instance, the British government introduced social studies curriculum into their educational system after the First and Second World Wars importantly to address social problems, pacify the conscience of the citizens to obey constituted authority, and contribute positively towards societal development (Edinyang \& Ubi, 2013). Social studies as a subject was included in the Nigerian schools as a quest for relevance in Nigerian education and society. This explains why social studies as a subject have been given an honorable place in the basic education level in Nigeria, starting from primary to junior secondary level of the Nigerian educational sector (Awhen, Edinyang, \& Ipule, 2014). Social studies curriculum was designed in such a way that it has the potentials to equip the learners with the needed skills to be abreast and survive in their environment (Nigerian Educational Research and Development Council, NERDC, 2013). NERDC in 2014 introduced social studies as a theme in a single subject "Religion and National value curriculum" and recently renamed it "National Values" 
in July, 2017 (National Universities Commission, 2017). This is to sensitize the value system of social studies. The National Policy on Education (NPE) (Federal Republic of Nigeria, 2013) clearly stipulated social studies curriculum overall objectives as: development of ability of the students to the changing environment; becoming responsible and disciplined individuals who are capable and willing to contribute to the development of the society; inculcating the right type of values; developing sense of comprehension towards other people, their diverse cultures, history and those fundamental things that make them human and developing a sense of solidarity and sharing, based on a sense of security in one's own identity. Social studies as an implemented curriculum is foundational to a great number of social science-based professional courses for learners (Godfrey, 2009). It addresses economic, political, psychological, physical and technological relevance of the cultural and moral way of life of a people to national development. Its content is organized around social and environmental issues affecting man's existence, ability to perform, and conserve the environment for sustainable development (Mezieobi, Akpochafo, \& Mezieobi, 2010). Social studies curriculum is one of such programmes that deserve national attention especially in the planning of the curriculum.

Curriculum is planned, considering the target audience in order to achieve effective learning through an appropriate means or method of implementation. Curriculum itself, is a deliberately and systematically planned body of knowledge, skills and attitudes grouped into subject topics taught to learners in schools (Ikehi, Ifeanyieze, \& Ugwuoke, 2014). According to the authors, the teaching process is the main implementation action of the curriculum of any subject. The term curriculum implementation is often referred holistically as all aspects of educational experience within the reach of the student in the school (Mkpa \& Izuagba, 2012). It is a process through which stated policies by the curriculum planners and developers are transcribed into practice such as the discharge of instruction by the teacher in the classroom (Mkandawire, 2013). Sometimes, the effectiveness of the teacher in the discharge of instructions in the classroom depends on his/her years of experience, exposure and qualifications.

Teacher quality and qualifications have great impact on curriculum implementation. Professional and academic qualifications of teacher are two vital concepts which cannot be separated in an attempt to analyze the effectiveness of the teacher in curriculum implementation. Teacher qualification is one of the elements that produce a positive result in instructional delivery of social studies (Nwaubani, Ottoh-Offfong, Usulor, \& Okeke, 2016). In admonition, Okam (2012) stressed that only professionally trained social studies teachers can successfully produce a desired result in instructional delivery. The training of teacher then is important before engaging in curriculum implementation, since another qualifier for the name teacher is curriculum implementer ( $\mathrm{Mkpa}$ in $\mathrm{Ob}$ ilo \& Sangoliye, 2010). The training is expected to expose the teacher to necessary skills, knowledge of the curriculum content, and proper utilization of in- 
structional resources in order to become an effective teacher (Okoro, Emenyonu, \& Akaraonye, 2012). The NPE has prescribed a minimum of National Certificate in Education (NCE) as the basic qualification for junior secondary school teachers in Nigeria (FRN, 2013). This is to ensure that those who go into the teaching profession have the basic educational qualification and teaching background. It is equally advocated that those who teach social studies should possess Bachelor's Degree and other higher qualifications in social studies to advance quality implementation of the programme. As a matter of fact, the absence of well trained and qualified teachers of social studies would make it difficult to deliver effectively a workable educational system in Nigeria (Nwaubani, Otto-Offong, Usulor, \& Okeke, 2016). This implies that for Nigeria to have a functional and quality educational system, it must constantly endeavor to produce qualified teachers who are competent enough in the coverage of vital subjects such as social studies.

Teachers' coverage of social studies content is a vital aspect of curriculum implementation. It is traditionally known that for an effective teaching and learning, the teacher must have the knowledge of what to be taught which is "content knowledge". In the opinion of Markley (2012) an effective teacher is one who demonstrates knowledge of the curriculum. Teacher's knowledge of what to deliver helps them to cover the subject content. Factors such as content knowledge, instructional objectives, verbal ability, certification and experience enhance social studies content coverage (Boadu, Bordoh, Eshum, Bassaw, \& Andoh-Mensah, 2014). However, Umadi (2012) opined that the unique nature of social studies education appears to draw extra ordinary attention to the fact that at all stages of its teaching process and content implementation are always problematic. Based on this notification, it is important for the curriculum developers to take into consideration the proper means to ensure that what has been designed is properly implemented to ensure the actualization of the objectives of social studies.

The objectives of social studies could be realized when qualified teachers who are familiar with content knowledge, are engaged among other factors such as location. Location is also a key factor in implementation. Inequality in development of urban and rural locations possibly affects teachers' effectiveness, learners' interest and achievement, thus influencing the extent of the implementation of social studies curriculum especially in Enugu State. It is essential for every segment of the state to have equal access and perception of educational issues. Geographically, Enugu is one of the states in South-East zone of Nigeria. it is the capital of old Eastern Region and it is still looked at as the capital of the South Eastern states. Enugu is significant in igbo land as it is regarded as the oldest urban city in the South East Nigeria. The cosmopolitan nature of Enugu State made it house a lot of people from different background who have come to settle there. Effective implementation of social studies curriculum would benefit a whole lot of people. Enugu State has six Education zones namely: Agbani, Enugu, Agwu, Nsukka, Obollo-Afor and Udi. Three of the education zones (Enugu, 
Agbani \& Nsukka) are urban with few rural areas while the other three (Udi, Agwu \& Obollo-Afor) are considered rural. Arthur (2011) emphasized that location affects teacher effectiveness. Arthur maintained that some schools, especially government secondary schools in the rural areas lack subject teachers, and those who are not professionally trained end up teaching some subjects. Concerns have been expressed over the rapid increment in terms of teacher's ineffectiveness and lack of learners' interest in the implementation of social studies curriculum. The above scenario could negate the very purpose for which social studies was introduced in Nigerian schools. Social studies as a subject of study is the foundation of social-cultural values for building a reliable and sustainable society. Social studies programme provides knowledge, skills and the right attitudes that would enable learners to understand their physical and natural environment; in order to be equipped for responsible citizens. If the subject is not properly implemented, and learners interest motivated, the intended goal of social studies could not be achieved even when the curriculum has been found to be adequate in terms of objectives. One would want to know the extent of implementation of social studies in Enugu State. Literature is depleted on studies that had done this within this locality. From the foregoing there is need to determine the extent of the implementation of social studies curriculum in Enugu State. This study focused on two important factors which the researcher considered among others imperative towards investigating the extent of implementation of social studies curriculum in secondary schools in Enugu State. To achieve this, the study was guided by the following research questions and hypotheses:

\section{Research Questions}

1) To what extent do teachers' academic qualifications affect their ability to implement social studies curriculum in urban and rural secondary schools in Enugu State.

2) To what extent do teachers in urban and rural secondary schools of Enugu State achieve coverage of social studies content in the implementation of social studies curriculum?

\section{Hypotheses}

1) There is no significant difference in the mean ratings of teachers in urban and rural secondary schools on the extent to which teachers' academic qualifications affect their ability to implement social studies curriculum.

2) There is no significant difference in the mean ratings of teachers in urban and rural secondary schools on the extent to which they achieve content coverage in the implementation of social studies curriculum.

\section{Methodology}

Descriptive survey research design was adopted for the study. Creswell (2014) stated that descriptive survey involves gathering data that describe events and then organizes, depicts, and describes the data collected without any manipulation. A descriptive survey research design is a design that studies both small and 
large population by collecting and analyzing data by the use of questionnaires or interview in order to make generalization or inferences. Survey research design is appropriate for any study that requires the opinion of respondents. The area of the study is Enugu State. Enugu is one of the states in South-East geo-political zone of Nigeria. It is the capital of old Eastern Region and it is still looked at as the capital of the South Eastern states. The population of the study consisted of all 339 social studies teachers in 291 urban and rural public secondary schools in the six education zones in Enugu State. The population spread per education zones are as follows: Agbani has 41, Agwu 22, Enugu 84, Nsukka 86, Obollo-Afor 59 and Udi 47. The total is 339 social studies teachers. 209 respondents are from urban schools while 130 are from the rural schools. There was no sampling in this study. The entire population was used because the number of teachers is 339 and was considered very manageable. The instrument used for data collection was developed by the researcher and captioned "Extent of Implementation of Social Studies Curriculum Questionnaire" (EISSCQ). The questionnaire was divided into two sections $\mathrm{A}$ and $\mathrm{B}$, of which the $\mathrm{A}$ part contains the demographic information of respondents while section $B$ contains questionnaire items on the indices of social studies implementation being examined in the study. Section B was arranged in two clusters A and B in line with the two research questions and two hypotheses. Cluster A had detailed information on teachers' academic qualification as well as those on the location of respondents. Cluster B contains items on the extent to which teachers in urban and rural secondary schools achieve coverage of social studies content in the implementation of social studies curriculum. The instrument had 18 items of which cluster A comprised 8 questionnaire items while cluster B had 10 items. The instrument was structured on a four-point Likert type scale of very great extent (VGE), great extent (GE), low extent (LE) and very low extent (VLE). The questionnaire was designed to match the research questions. The respondents were requested to tick the option that best suits their opinion. The researcher also attached an introductory letter to the instrument to establish rapport with the respondents.

The questionnaire was subjected to face validation which required a close examination of the items. One specialist each from curriculum and instruction, social studies education and measurement and evaluation from Faculty of Education, Godfrey Okoye University, Enugu State, validated the instrument. The questionnaire was validated with reference to its comprehensiveness, relevance to content, possible errors, omissions and clarity of purpose. The validation was carried out in order to ascertain that the instrument was suitable and appropriate for the study. The reliability of the instrument was acertained by trial testing it on the sample of 40 teachers from schools outside the Enugu State. The researcher administered 40 copies of the instrument to 40 social studies teachers in Awka education zone in Anambra State. The teachers were randomly selected from 10 public secondary schools from urban and rural location. The reliability coefficient of 0.75 and 0.78 were obtained for clusters A and B with a reliability 
coefficient of 0.77 for the whole instrument. The value of 0.77 obtained attest to the high reliability of the instrument.

To carry out the study, School principals were officially informed and their approval was obtained. Nine research assistants were trained and used to cover the six education zones of Enugu, Udi, Agbani, Agwu, Obollo-Afor and Nsukka. The questionnaire was self-administered by the research assistants and the researcher. Two research assistants covered Agbani zone, two assistants covered Agwu, two research assistants covered Nsukka and Obollo-Afor while two covered Udi Education zone. The researcher and one assistant covered Enugu Education zone. Responses were collected on the same day. Data were successfully collected within one month. There was no misplacement of the instrument. Mean and standard deviation were used to answer the research questions. Mean was considered because it has a higher reliability compared to other measures of central tendency. The hypotheses were tested using t-test at 0.05 level of significance.

\section{Results}

Data are presented according to the research questions answered and hypotheses tested.

Research Question 1: To what extent do teachers' academic qualifications affect their ability to implement social studies curriculum in urban and rural secondary schools in Enugu State?

Table 1 shows that teachers in urban area had a mean rating of 2.59 with standard deviation of 1.06, while those in rural area had mean rating of 2.53 and standard deviation of 0.90 . The value of the grand mean was 2.68 with standard deviation of 0.97 . This indicates that academic qualifications of teachers in urban and rural locations affect them to a great extent on the implementation of social studies curriculum.

Research Question 2: To what extent do teachers in urban and rural secondary schools of Enugu State achieve coverage of social studies content in the implementation of social studies curriculum?

Table 2 shows that respondents in urban location had mean ratings of 3.22 , $3.11,3.23,2.88,2.89,2.72,2.80,2.88,2.82$ and 2.83 for items one to ten respectively. A grand mean of 2.93 with SD 1.01 was recorded. All the mean values were higher than the cut-off point of 2.50. This implies that teachers in urban schools cover social studies curriculum content to a great extent. However, teachers in rural zone had grand mean of 2.45. The grand mean value is less than the cut-off point of 2.50. This indicates that teachers in rural schools achieve coverage of social studies content to a low extent.

Hypothesis 1: There is no significant difference in the mean ratings of teachers in urban and rural secondary schools on the extent to which their academic qualifications affect their ability to implement social studies curriculum.

Table 3 shows that the t-value for the difference in mean ratings of teachers 
Table 1. Mean Ratings and standard deviation of social studies teachers regarding the extent to which their academic qualifications affect their ability to implement social studies curriculum in secondary schools $(\mathrm{N}=339)$.

\begin{tabular}{|c|c|c|c|c|c|c|c|c|c|c|}
\hline \multirow{2}{*}{$\mathrm{S} / \mathrm{N}$} & \multirow{2}{*}{ Item Statements } & \multicolumn{3}{|c|}{ Urban } & \multicolumn{3}{|c|}{ Rural } & \multicolumn{3}{|c|}{ Avg. Response } \\
\hline & & Mean & SD & Dec & Mean & SD & Dec & Mean & SD & Dec \\
\hline 1. & $\begin{array}{l}\text { Teachers with academic qualifications of NCE in social studies have the } \\
\text { ability to implement social studies }\end{array}$ & 2.90 & 1.11 & GE & 2.99 & 0.70 & GE & 2.94 & 0.90 & GE \\
\hline 2. & $\begin{array}{l}\text { Teachers with academic qualifications of Sc.Ed in social studies are in } \\
\text { better position to implement social studies }\end{array}$ & 2.39 & 1.14 & LE & 1.96 & 1.09 & $\mathrm{LE}$ & 2.17 & 1.11 & LE \\
\hline 3. & $\begin{array}{l}\text { Teachers with academic qualification of B.A and Post Graduate Diploma } \\
\text { in education (PGDE) have the ability to implement social studies }\end{array}$ & 2.36 & 1.09 & $\mathrm{LE}$ & 2.03 & 0.76 & $\mathrm{LE}$ & 2.19 & 0.92 & LE \\
\hline 4. & $\begin{array}{l}\text { Teachers with academic qualification of B.A in other areas can } \\
\text { implement social studies better }\end{array}$ & 1.92 & 0.99 & $\mathrm{LE}$ & 1.43 & 0.68 & $\mathrm{LE}$ & 1.67 & 0.83 & LE \\
\hline 5. & $\begin{array}{l}\text { Teachers with Bachelors of Education (B.Ed) in related areas are better } \\
\text { prepared to implement social studies curriculum }\end{array}$ & 2.09 & 1.00 & LE & 2.18 & 0.99 & $\mathrm{LE}$ & 2.13 & 0.99 & LE \\
\hline 6. & $\begin{array}{l}\text { Teachers with Bachelors of Education (B.Ed) in social studies are } \\
\text { poised to teach social studies }\end{array}$ & 2.99 & 1.06 & GE & 3.57 & 0.99 & GE & 3.28 & 1.02 & GE \\
\hline 7. & $\begin{array}{l}\text { Teachers with master in education (M.Ed) in social studies are poised } \\
\text { to implement social studies better }\end{array}$ & 3.03 & 1.12 & GE & 2.75 & 1.03 & GE & 2.89 & 1.07 & GE \\
\hline 8. & $\begin{array}{l}\text { Teachers with Doctor of philosophy in social studies Education (Ph.D) } \\
\text { are better equipped to implement social studies programme }\end{array}$ & 3.08 & 1.00 & GE & 3.38 & 0.97 & GE & 3.23 & 0.98 & GE \\
\hline \multicolumn{2}{|c|}{ Grand } & 2.59 & 1.06 & GE & 2.53 & 0.90 & GE & 2.68 & 0.97 & GE \\
\hline
\end{tabular}

$\mathrm{SD}=$ Standard deviation; $\mathrm{DEC}=$ Decision; VGE $=$ Very great extent GE $=$ Great extent LE $=$ Low extent VLE $=$ Very low extent.

Table 2. Mean Ratings and standard deviation of teachers on the extent to which they achieve coverage of social studies content in the implementation of social studies curriculum $(\mathrm{N}=339)$.

\begin{tabular}{|c|c|c|c|c|c|c|c|c|c|c|}
\hline \multirow{2}{*}{ S/N } & \multirow{2}{*}{ Item Statements } & \multicolumn{3}{|c|}{ Urban } & \multicolumn{3}{|c|}{ Rural } & \multicolumn{3}{|c|}{ Avg. Response } \\
\hline & & Mean & SD & Dec & Mean & SD & Dec & Mean & SD & Dec \\
\hline 1. & Teachers cover meaning and objectives of social studies & 3.22 & 0.90 & GE & 3.11 & 0.76 & GE & 3.16 & 0.83 & GE \\
\hline 2. & They cover people and their environment & 3.11 & 0.95 & GE & 2.43 & 1.08 & $\mathrm{LE}$ & 2.77 & 1.01 & GE \\
\hline 3. & Family, types of family and family bond & 3.23 & 0.89 & GE & 2.80 & 0.97 & GE & 3.01 & 0.93 & GE \\
\hline 4. & Common social problems in Nigeria & 2.88 & 0.90 & GE & 2.33 & 1.13 & $\mathrm{LE}$ & 2.60 & 1.01 & GE \\
\hline 5. & Cultures and different types of culture in Nigeria & 2.89 & 1.10 & GE & 2.70 & 0.85 & GE & 2.79 & 0.97 & GE \\
\hline 6. & Individuals and group behaviour & 2.72 & 2.08 & GE & 2.22 & 0.93 & $\mathrm{LE}$ & 2.47 & 1.00 & $\mathrm{LE}$ \\
\hline 7. & Corruptions and different acts of corruption found in Nigeria & 2.80 & 1.04 & GE & 2.20 & 0.93 & LE & 2.47 & 1.00 & $\mathrm{LE}$ \\
\hline 8. & Promotion of peaceful living in Nigeria & 2.88 & 1.08 & GE & 1.94 & 0.92 & LE & 2.41 & 1.00 & $\mathrm{LE}$ \\
\hline 9. & Social values & 2.82 & 1.08 & GE & 2.70 & 1.00 & GE & 2.76 & 1.04 & $\mathrm{LE}$ \\
\hline 10. & Drug trafficking and its effect & 2.83 & 1.13 & GE & 2.11 & 0.92 & LE & 2.47 & 1.02 & LE \\
\hline & Grand & 2.93 & 1.01 & GE & 2.45 & 0.93 & LE & 2.69 & 0.78 & GE \\
\hline
\end{tabular}

$\mathrm{SD}=$ Standard deviation; $\mathrm{DEC}=$ Decision; VGE = Very great extent; GE = Great extent; LE = Low extent; VLE = Very low extent.

Table 3. t-test analysis of responses of teachers in urban and rural secondary schools on the extent to which their academic qualifications affect their ability to implement social studies curriculum.

\begin{tabular}{cccccccc}
\hline Location & $\mathbf{N}$ & Mean & SD & t-cal & Df & Sig. & Dec. \\
\hline Urban & 209 & 2.59 & 1.06 & 3.27 & 337 & 0.17 & NS \\
Rural & 130 & 2.54 & 0.90 & & & & \\
\hline
\end{tabular}


in urban and rural schools on the extent to which teachers' academic qualifications affect their ability to implement social studies curriculum is 3.273 at 0.05 level of significance and 337 degree of freedom. This is not significant at 0.166 level, since it is higher than the significant level of 0.05 set for the study. The null hypothesis is therefore, not rejected as stated. Hence there is no significant difference in the mean ratings of teachers in urban and rural secondary schools on the extent to which their academic and professional qualifications affect their ability to implement social studies curriculum.

Hypothesis 2: There is no significant difference in the mean ratings of teachers in urban and rural secondary schools on the extent to which they achieve coverage of social studies content in the implementation of social studies curriculum.

Table 4 shows that the t-value for the difference in mean ratings of teachers in urban and rural schools on the extent to which they achieve coverage of social studies content in the implementation of social studies curriculum is 4.300 at 0.05 level of significance and 337 degree of freedom. This is significant at 0.003 level of significance, since it is less than the significant level of 0.05 set for the study. The null hypothesis is therefore, rejected. Hence, there is a significant difference in the mean ratings of teachers in urban and rural secondary schools on the extent to which they achieve coverage of social studies content in the implementation of social studies curriculum.

\section{Discussion of Results}

The results in Table 1 showed that academic and professional qualifications of teachers to a great extent, affected their ability to implement social studies curriculum. Data revealed that teachers who have academic qualifications of NCE, B.Ed, M.Ed and Ph.D in social studies delivered social studies subject matter better in the classroom. It was found that teachers with B.Sc.Ed in Social Studies, B.A and Post Graduate Diploma in education, B.A in other areas and B. Ed in related areas are not in the best position to teach social studies. Furthermore, t-test analysis of hypothesis one showed that there was no significant difference in the mean ratings of teachers in urban and rural secondary schools on the extent to which academic qualifications of teachers affected their ability to implement social studies curriculum. This finding by implication suggests that teachers from discipline other than social studies are not in the best position to teach the subject. When they do, the result would yield not too favourable results.

Table 4. t-test analysis of responses of teachers in urban and rural secondary schools on the extent to which they achieve coverage of social studies content in the implementation of social studies curriculum.

\begin{tabular}{cccccccc}
\hline Location & N & Mean & SD & t-cal & Df & Sig. & Dec. \\
\hline Urban & 209 & 2.94 & 1.02 & 4.30 & 337 & 0.003 & NS \\
Rural & 130 & 2.45 & 0.94 & & & & \\
\hline
\end{tabular}


The result agrees with the finding of Nwanekezi and Ibekwe (2017) who discovered that social studies teachers' academic qualifications had a significant influence on the effective implementation of social studies curriculum. It could imply that qualified social studies teachers make more impact on implementation of the curriculum than those who have not been specially trained to teach the subject. Curriculum implementation requires teachers who are academically and professionally qualified in their field of study. This in essence is why Nwaubani, Ottoh-Offong, Usulor and Okeke (2016) opined that teacher qualifications are the major elements that produce positive results in instructional delivery of social studies. This means that qualified social studies teachers are needed to make learning meaningful in social studies teaching and learning. Against this knowledge, it is relatively not encouraged to allow teachers from the related or unrelated fields to teach social studies. Contrary to this finding, Namamba and Rao (2017) in their study on "influence of teachers' professional qualification and areas of specialization on the implementation of environmental education in Cross River State, Nigeria" discovered that teachers' professional qualifications and area of specialization did not significantly influence the implementation of environmental education curriculum in Cross River State. The result obtained could be peculiar to Cross River State. It could be that there are not enough trained and qualified teachers to teach the subject. It could also be that teachers in Cross River State have had some idea of environmental education. For that reason, they could handle the course irrespective of their qualifications and areas of specialization. However, in addition, Okam (2012) stressed that only professionally trained social studies teachers can successful produce a desired result in instructional delivery.

The result of the analysis showed that teachers in urban secondary schools achieved coverage of social studies content to a great extent while teachers in rural schools achieved coverage of social studies content to a low extent. The result obtained could be as a result of schools in the urban locations having more social studies teachers than schools in the rural areas. Going by the statistics the researcher obtained from Post Primary School Management Board (PPSMB), most schools in the rural areas had zero specialist of social studies teachers. Furthermore, the t-test analysis of hypothesis two showed that there was a significant difference in the mean ratings of teachers in urban and rural secondary schools on the extent to which they achieved coverage of social studies content in the implementing of social studies curriculum. This result implied that there was a disparity in the coverage of social studies content by teachers in urban and rural schools. This result could be as a result of the fact that teachers in rural schools must not have had good knowledge of the effects of non-coverage of the curriculum while their counterparts in urban schools were very conscious of the impact of constant and good instructional delivery on the students.

This finding in respect to teachers in urban schools agrees with the submissions of Boadu, Bordoh, Eshum, Bassaw and Andoh-Mensah, (2014) that teach- 
ers' coverage of social studies content is a vital aspect of curriculum implementation. This finding is also in line with Kankam, Bordoh, Eshum and Bassaw (2015) that the importance of content knowledge has attracted the attention of policy makers; hence programmes, workshops have been organized to equip teachers with necessary knowledge for their professional development. It is obvious that teachers' inability to cover the subject content would necessarily influence the outcome of instruction. Students would not be able to learn all that is required of them to be better individuals with the capacity of serving the society at large. Boadu, Bordoh, Eshum, Bassaw and Andoh-Mensah (2014) study of "teachers' content knowledge impact on students in the senior high schools in Ghana" buttressed the above assertion. They identified that content knowledge which is necessary for proper coverage of the curriculum in order to impact skills, values and knowledge to students was lacking in the selected teachers. Furthermore, as regards the present study, teachers from urban schools must have had good knowledge of social studies content in order to achieve its coverage. Regarding urban and rural disparity, Kanno (2006) was of the opinion that students within the urban area receive quality education while those from rural areas are not very properly taught. This view of Kanno implies that urban and rural situation of schools create gaps in students learning.

\section{Conclusion and Recommendation}

Studies in social sciences aimed at proving useful outcomes that would go a long way to influence school students' morality and value for the society. Effective implementation of social studies curriculum would adequately help students, who are the present youths and future leaders, to acquire the vital skills and attitudes required for good morality and nation building. The effective implementation of social studies is expected to help with youth character formation to ensure a stable, peaceful and progressive society and nation. However, inadequate coverage of social studies content poses a challenge to social studies curriculum implementation especially in the rural schools. This deficiency in teaching could lead to producing students who are not grounded in the subject thus are not morally well-formed. The consequences of poor implementation of social studies range from disorderliness among youths, poorly behaved youths leading to consistent sabotage of economy to insecurity.

The study hopes to attract ministries of education, both federal and state since they are in position to make teaching appointments and fresh recruitments. Findings from the study would enable ministry of education to focus on recruiting and deploying credible teaching personnel in both urban and rural locations to ensure equality for quality education. The study provides an idea on how curriculum implementers are carrying out their responsibilities. It would also serve as a guide in deciding whether to effect a change, revise the curricula delivery approach, innovate or improve the existing social studies teaching plan. A policy should be enacted by the federal government in collaboration with the state 
ministry of education to employ only qualified and specialist social studies teachers to teach the subject. The study also recommends the encouragement and support of secondary school teachers to pursue academic development to improve their performance. Regular workshops, seminars or on-the-job trainings should be organized by the ministry of education to update and upskill social studies teachers' knowledge and skills in content delivery.

\section{Limitations of the Study}

Only teachers constituted the respondents for this study. The views of school principals who are co-implementers of curriculum in all subject areas would like to have impact on the data collected.

\section{Conflicts of Interest}

The authors did not declare any conflict of interest.

\section{References}

Adesina, A. E. (2011). Perceived Impact of Primary Education on the Attainment of Nigerian Vision 2020. Mediterranean Journal of Social Sciences, 2, 2117-2039.

Aja-Okorie, O. (2013). Women Education in Nigeria: Problems and Implications for Family Role and Stability. European Scientific Journal, 9, 227. http://eujournal.org/index.php/esj/article/view/1897

Arthur, U. I (2011). The Implementation of Core English Language Programme in the Senior Secondary Schools in Ghana. The Case of Some Selected Schools in the Ashani Region. Master's Dissertation, Cape Coast: University of Cape Coast.

Awhen, O. F., Edinyang, S. D., \& Ipule, O. D. (2014). Introduction of Social Studies Education in Nigerian Schools: A Success or a Failure. International Journal of Education and Research, 2, 347-352.

Boadu, K., Bordoh, A., Eshum, I., Bassaw, T. K., \& Andoh-Mensah, C. (2014). Social Study Teacher's Content Knowledge Impact on Students in Senior High Schools in Ghana. Open Science Journal Education, 2, 73-82.

Creswell, J. W. (2014). Qualitative Inquiry and Research Design: Choosing among Five Traditions. Thousand Oaks, CA: Sage Publications.

Edinyang, S. D., \& Ubi, I. E. (2013). Gender, Socio-Economic Status, Teacher Qualification and Their Interaction on Students' Retention Ability in Social Studies in AkwaIbom State Nigeria. International Knowledge Sharing Platform, 2, 35-40.

Federal Republic of Nigeria (2013). National policy on Education (6th ed.). Lagos: NERDC Press.

Godfrey, A. B. (2009). Juran's Quality Hand Book. http://www.nrc.gov/reading-rm/doc-collections/cfr/partoso/parto56-appb.htm

Ikegbusi, N. G. (2012). Teachers Tortious Liability to Students as a Correlate of Their Discipline in Anambra State Secondary Schools. Unpublished Ph.D. Dissertation, Awka: Nnamdi Azikiwe University Awka.

Ikehi, M. E., Ifeanyieze, F. O., \& Ugwuoke, C. U. (2014). Integration of Climate Change into the Senior Secondary School Agricultural Science Curriculum in Nigeria. Journal of Atmospheric and Climate Sciences, 4, 614-621.

https://doi.org/10.4236/acs.2014.44054 
Kankam, B., Bordoh, A., Eshun, I., \& Bassaw, T. K. (2015). Social Studies Teachers' Content Knowledge Impact on Students in the Senior High Schools in Ghana. Open Science Journal of Education, 2, 73-82.

Kanno, T. N. (2006). Teaching Practice Micro Teaching and Methodology of Educcation in Nigeria. Lagos: Unique Publishers.

Markley, T. (2012). Defining the Effective Teacher, Current Arguments in Education, White Mountains Regional Schools District, New Hampshire.

Mezieobi, D. I., Akpochafo, W. P., \& Mezieobi, S. A. (2010). A Review of Social Studies Education Implementation in Nigerian Secondary Schools. Nigerian Journal of Curriculum Theorist and Education Technologist, 1, 126-143.

Mkandawire, S. B (2013). Impediments of Curriculum Implementation in Learning Institutions. Lubaka: Image Publishers.

Mkpa, M. A., \& Izuagba, A. C (2012). Curriculum Studies and Innovation (Revised). Owerri: Divine Mercy Publishers.

Namamba, A., \& Rao, C. (2017). Preparation and Professional Development of Teachers' Educators in Tanzania: Current Practices and Prospects. Journal of Education and Practice, 8, 136-145.

National Council of the Social Studies (2004). Expectations of Excellence: Curriculum Standards for Social Studies. Washington DC: NCSS Press.

National Universities Commission (2017). National Council of Education Returns History and Religious Studies Back to Basic School Curriculum.

http://nuc.edu.ng/national-council-of-education-returns-history-and-religious-studiesback-to-basic-school-curriculum

Nigerian Educational Research and Development Council (2013). Teachers' Guide for the Revised 9-Year Basic Education Curriculum (BEC) Religion and National Values Social Studies. Abuja: NERDC Press.

Nwanekezi, A. U., \& Ibekwe, M. P. (2017). Teachers' Academic Qualification and Teachers' Years of Teaching Experience: Effective Implementation of Upper Basic Social Studies Curriculum in Rivers State. International Journal of Scientific Research in Education, 10, 347-361.

Nwaubani, O. O., Otoh-Offong, A. N., Usulor, V. I., \& Okeke, J. N. (2016). Teacher Qualification as a Factor in the Utilization of Instructional Facilities for Effective Implementation of Social Studies Curriculum in Ebonyi State, Nigeria. Journal of Applied Sciences Research, 12, 21-28.

Obasi, V. A., Kanno, T. N., \& Obih, S. O. A. (2017). Curriculum Implementation in Contemporary Issues. In T. N. Kanno (Ed.), Curriculum Implementation. Owerri: Hysab Publishers.

Obilo, I. P., \& Sangoloye, S. A. (2010). Curriculum Implementation and the Teacher: Challenges and Way forward.

Odey, J. (2014). The Headquarters of Exam Malpractice (Part 3). The Voice.

Ofojebe, W. N. (2014). Integrating Peace Education into the Nigerian Basic Education Curriculum for a Lasting Peace and Environmental Sustainability. European Scientific Journal, 10, 1837-7881.

Okam, C. C. (2012). Teaching Issues, Insights and Problems in Social Studies Education in Nigeria. Jos: Deka Publication.

Okoro, I. F., Emenyonu, C., \& Akaraonye, J. (2012). The Idea of Curriculum Implementation. In I. F. Okoro (Ed.), Essentials of Curriculum Implementation. Owerri: Doming 
Prints.

Umadi, A. B. (2012). Content Implementation in Junior Secondary Schools in Nigeria. Nigerian Journal of Curriculum and Instruction.

http://www.globalacademicgroup.com 